\title{
Master of Engineering
}

National Cancer Institute

\section{Source}

National Cancer Institute. Master of Engineering. NCI Thesaurus. Code C71368.

A master's degree in engineering awarded after the completion of a program of one to three years in duration. This acknowledgment comprises about 4-6 years of university study in total with a focus in the field of eng ineering. 